UDC 331.101

JEL Classification: M54, M12

http://doi.org/10.21272/mmi.2018.4-03

Anastasiia Shvets,

Signify, the Netherlands

\title{
INNOVATIVE APPROACHES TO ANALYSIS OF JOB QUALITY: FACTORS, ELEMENTS AND OUTCOMES
}

Abstract. The aim of the research is to systemize the variety of general and detailed knowledge of job quality. The study contains generalization and structuring of the global scientific heritage regarding the concept of job quality issue and well-being, job satisfaction and the relationship between them. It is underlined that over the years, the concept of job quality has been widely researched by scholars of different fields, has been widely discussed by policymakers and researched by scholars of different fields. Job quality has become a widely discussed issue due to its importance in the formation of the employee's, company's, and, consequently, national wellbeing. The authors proposed innovative approaches to the analysis of labour quality, which are reflected in five parts of the article, each of which deals with the study regarding the specific aspects of the job quality. In the first part of the article, the conceptual overview of job quality and its dimensions were analysed. Based on the results of the initial evaluation of empirical studies, a general model of the factors and outcomes of job quality was built. The second part of the article deals with the theoretical investigation of the main categories, such as job quality and well-being, subjective well-being and affective well-being, job satisfaction, affective organizational commitment. The structure of job-related affective well-being is described. The construct of affective well-being is used as a basis for meta-analysis. According to the results of the literature search, different elements of job quality was found to be related to such outcomes as job satisfaction and organizational commitment. The third part of the article describes the dimensions of job quality. Three dimensions of job quality - pay satisfaction, autonomy, and job security - were elaborated in relation to the affective well-being of the employee. The hypothesized model of job quality elements and outcomes that were meta-analysed was developed. The fourth part of the article describes the meta-analysis of the key aspects of the general concept and a general model of the job quality construct which consists of the job quality factors, elements and outcomes. This part provides a meta-analytical review, which is based on the method of psychometric meta-analysis, of the relationships between job security, as an individual level construct, pay satisfaction, autonomy and the employee's job-related affective well-being. The fifth part of the article describes the results of the meta-analysis. Firstly, the results of the relationship between job security at the individual level and job-related affective well-being are provided. Secondly, the results of the relationship between pay satisfaction and affective well-being are presented. Finally, the results of the relationship between autonomy and job-related affective well-being are provided. The reported results also include the analysis of the moderating role of job security on those relationships.

Keywords: innovative approaches, job quality, job security, autonomy, meta-analysis, job satisfaction.

Introduction. The issue of job quality is becoming increasingly debated among social scientists and policy-makers. This growing attention to job quality is largely determined by its widely discussed importance in the national flourishing through the direct impact of job quality on the employee's and company's wellbeing. One of the questions that makes those debates difficult and does not let them reach a new level is what job quality actually is. After almost two decades of discussions and researches, scholars and policy-makers still, do not have a precise definition of job quality.

Some scientists have studied job quality as an employee's individual perception of their jobs and working conditions, while others have examined the differences in job quality in various companies, industries and occupations. However, some of the authors dedicated their researches to the explanation of macro-level factors that may determine differences in job quality in various countries and institutional regimes.

Another level of job quality studies and its definition is induced by the discussions whether job quality

Cite as: Shvets, A. (2018). Innovative Approaches to Analysis of Job Quality: Factors, Elements and Outcomes. Marketing and Management of Innovations, 4, 26-42. http://doi.org/10.21272/mmi.2018.4-03 
is an objective or subjective construct. The arguments in support of the subjective perspective were illustrated by the results of the European research project SPReW (SPReW, 2012). This study was aimed at the investigation of the differences in the subjective perception of work among the three current generations of working age - the baby boomers (born before 1960), the so-called generation X (born between 1960 and 1980), and the so-called Generation Y (born after 1980). The first studied group was reported to be highly concerned about the acknowledgement of work experiences and improved working conditions; the second group of generation $X$ showed a strong interest in reconciling family and work and lifelong learning; finally, the representatives of generation $Y$ asked for more individual autonomy, social protection, and higher income. Those results clearly illustrate that there are subjective differences in the perception of job among different generations. The study shows that the context of job quality is changing quickly in the perception of individuals from different generations. However, those differences in the employees' job expectations and their definition of job quality may also exist between individuals of a certain generation. So, job quality appears to be an idiosyncratic construct, the picture of which is formed at the individual level and is unique for every particular employee. This raises the question of what actually determines job quality for the individual.

Previous research shows that the role of one job quality element is becoming increasingly important in the formation of job quality construct in the employee's perception. A rapidly changing business environment and growing level of acceptable external uncertainty, which comes from new trends at the labour market - for instance, the increased use of temps and contract workers, - raised the need to reflect the effect of those factors in the job quality construct. The job quality element that integrates those factors is job security. Job security is a relatively new dimension of job quality and its impact on job quality has not been fully discovered yet.

Job security is a phenomenon that can be studied at different levels. This article will focus on the metaanalysis of the individual and country levels of job security. There are two reasons for choosing those two levels. Firstly, individual and country levels reflect the internal (e.g., individual's ability to perform his or her job) and external (e.g., crisis in the country, high level of unemployment) conceptualization of job security respectively. This differentiation allows us to understand better the effect of job security on the job quality construct. Secondly, meta-analysis, as a research method, gives us an opportunity to discover the direct impact of the individual level job security on the chosen job quality outcome by integrating the results of empirical studies of this relationship. Moreover, it also allows us to study the moderating effect of job security by coding it at a country level.

Literature review. Many scientists' works are dedicated to theoretical and practical aspects of the job quality research. Some researchers (Green, 2006; Warr, 1990) define job quality as a set of work and employment-related features that promote the beneficial outcomes for the employee, particularly psychological and physical well-being and positive attitudes such as job satisfaction. However, Knox et al. (2011) argue that this definition refers only to the worker's well-being. Findlay et al. (2013) claim that goodquality jobs allow employees to develop and use their skills and offer a reasonable degree of challenge that is equal to the job demands and employee's capabilities. However, an opportunity for skill use and challenging work is not the only dimensions of job quality. The scholars propose different groups of the dimensions. Some of them integrate the objective terms, such as physical environment or working hours (e.g., Paisna et al., 2013), while the others are based on the subjective experience of the employee, such as job satisfaction or well-being (e.g., Holman, 2012).

In Table 1, a summary of common job quality dimensions in the initially reviewed literature is presented. Autonomy, job content and job security are the most frequently mentioned dimensions among scholars and international institutions. Job satisfaction is also widely used as a dimension of job quality while a lot of researchers (e.g., Dupre \& Day, 2007; Hosie et al., 2013; Okay-Somerville \& Sholarios, 2013; Zeytinoglu et al., 2013) define it as an outcome of job quality. 
Table 1 - Summary of job quality dimensions

\begin{tabular}{|c|c|}
\hline Dimension & Authors \\
\hline Autonomy and control & $\begin{array}{l}\text { Brand, 2006; Decarlo \& Agarwal, 1999; Drobnic \& Rodriguez, 2011; Esser \& Olsen, } \\
\text { 2012; Federici, 2013; Finn, 2001; Jercovic-Cosic et al., 2012; Handel, 2005; Hosie } \\
\text { et al., 2013; Kalleberg \& Vaisey, 2005; Layte et al., 2008; Kelliher \& Anderson, } \\
\text { 2008; Okay-Somerville \& Scholarios, 2013; Van Dun et al., 2012; Weaver, 1977; } \\
\text { Zipp, } 1991\end{array}$ \\
\hline $\begin{array}{l}\text { Job content (interesting } \\
\text { and challenging work, } \\
\text { creativity and skill variety) }\end{array}$ & $\begin{array}{l}\text { CEC, 2001a, 2003; Chalmers et al., 2005; Dupre \& Day, 2007; Handel, 2005; } \\
\text { Kalleberg \& Vaisey, 2005; Jercovic-Cosic et al., 2012; Loughlin \& Murray, 2013; } \\
\text { Okay-Somerville \& Scholarios, 2013; Smith et al., 2008; Van Dun et al., 2012; Zipp, } \\
1991\end{array}$ \\
\hline Job security & $\begin{array}{l}\text { CEC, 2001a, 2003; Chalmers et al., 2005; Esser \& Olsen, 2012; Handel, 2005; } \\
\text { Holman, 2012; Kuhnert et al., 1989; Zeytinoglu et al., } 2013\end{array}$ \\
\hline $\begin{array}{l}\text { Opportunity for skill use } \\
\text { and development }\end{array}$ & $\begin{array}{l}\text { CEC, 2001a, 2003; Chalmers et al., 2005; Holman, 2012; Hosie et al., 2013; Layte } \\
\text { et al., 2008; Okay-Somerville \& Scholarios, } 2013\end{array}$ \\
\hline Job prospects & $\begin{array}{l}\text { CEC, 2001a, 2003; Chalmers et al., 2005; Handel, 2005; Kelliher \& Anderson, } \\
\text { 2008; Piasna et al., } 2013\end{array}$ \\
\hline Work pressure, stress & $\begin{array}{l}\text { Handel, 2005; Kelliher \& Anderson, 2008; Loughlin \& Murray, 2013; Piasna et al., } \\
2013\end{array}$ \\
\hline Working hours & $\begin{array}{l}\text { CEC, 2001a, 2003; Chalmers et al., 2005; Drobnic \& Rodriguez, 2011; Piasna et } \\
\text { al., } 2013\end{array}$ \\
\hline Job satisfaction & Holman, 2012; Kelliher \& Anderson, 2008; Van Dun et al., 2012; Zipp, 1991 \\
\hline Wage & Chalmers et al., 2005; Handel, 2005; Holaman, 2012; Layte et al., 2008 \\
\hline Job flexibility & CEC, 2001a, 2003; Chalmers et al., 2005; Hill et al., 2001; Holman, 2012 \\
\hline Physical environment & CEC, 2001a, 2003; Handel, 2005; Layte et al., 2008; Piasna et al., 2013 \\
\hline Occupational status & Brand, 2006; Grip \& Wolbers, 2006; Loughlin \& Murray, 2013 \\
\hline Engagement & CEC, 2001a, 2003; Chalmers et al., 2005; Holman, 2012 \\
\hline Employment benefits & Brand, 2006; Chalmers et al., 2005 \\
\hline $\begin{array}{l}\text { The quality of workplace } \\
\text { interpersonal relationship }\end{array}$ & Handel, 2005; Van Dun et al., 2012 \\
\hline
\end{tabular}

Sources: compiled by author

The less common dimensions proposed by scholars are satisfaction with benefits (Kalleberg \& Vaisey, 2005), work stimulation (Dupre \& Day, 2007), well-being (Holman, 2012), gender equality, diversity and non-discrimination, overall work performance (CEC, 2001a, 2003b), information sharing, learning from customers and employees (Van Dun et al., 2012). Although there is no agreed list of the dimensions and the way they are measured, scholars stress the need for 'fit' or 'alignment' in the assessment of job quality (Findlay et al., 2013). Cooke et al. (2013) emphasize the importance of analysing job quality in relation to the life stage of the individual, his/her work and life values and the available job opportunities. Cooke et al. conclude that it is hardly possible to find an optimal mix of job components that constitute 'good job': no one shoe can fit all.

Different scholars investigated the variety of correlations between the factors that influence job quality, its elements and outcomes. The summary of an initial search of those studies is presented in Table 2.

According to the studies' results, the outcomes of the job quality are divided on direct and indirect. During the initial literature review process, a few striking features of job quality studies were identified. First, some scholars investigated the relationship between the factors and/or outcomes and particular elements of job quality (e.g., Brand, 2006; Layte et al., 2008), while the others focused their researches on the correlations between factors and/or outcomes and job quality in general (Kolev, 2005; Piasna et al., 2013). 
Table 2 - Review of the job quality studies

\begin{tabular}{|c|c|c|c|c|}
\hline \multirow{2}{*}{ Authors } & \multirow{2}{*}{ Factors } & \multirow{2}{*}{$\begin{array}{c}\text { Elements } \\
\text { (dimensions) }\end{array}$} & \multicolumn{2}{|c|}{ Outcomes } \\
\hline & & & Direct & Indirect \\
\hline 1 & 2 & 3 & 4 & 5 \\
\hline Brand, 2006 & Job displacement & $\begin{array}{l}\text { Occupational status } \\
\text { Job autonomy } \\
\text { Employer-offered } \\
\text { pension } \\
\text { Health insurance } \\
\text { benefits }\end{array}$ & & \\
\hline $\begin{array}{l}\text { Brown et al., } \\
2007\end{array}$ & Unemployment rate & Job quality & & \\
\hline $\begin{array}{c}\text { Caliendo et al., } \\
2012\end{array}$ & Marginal employment & $\begin{array}{l}\text { More stable post- } \\
\text { unemployment jobs }\end{array}$ & & \\
\hline $\begin{array}{c}\text { Cloutier- } \\
\text { Villeneuve, } \\
2012\end{array}$ & $\begin{array}{l}\text { Economic environment } \\
\text { Social policies } \\
\text { Working time } \\
\text { Education }\end{array}$ & Job quality & & \\
\hline $\begin{array}{c}\text { DeCarlo \& } \\
\text { Agarwal, } 1999\end{array}$ & & Autonomy & Job satisfaction & \\
\hline $\begin{array}{c}\text { Drobnic \& } \\
\text { Rodriguez, } \\
2011\end{array}$ & & $\begin{array}{l}\text { Working hours } \\
\text { Autonomy }\end{array}$ & $\begin{array}{l}\text { Work-life } \\
\text { balance }\end{array}$ & \\
\hline $\begin{array}{c}\text { Dupre \& Day, } \\
2007\end{array}$ & & $\begin{array}{l}\text { Work stimulation } \\
\text { Job clarity }\end{array}$ & Job satisfaction & $\begin{array}{l}\text { Health } \\
\text { Turnover } \\
\text { intentions }\end{array}$ \\
\hline $\begin{array}{l}\text { Esser \& Olsen, } \\
2012\end{array}$ & $\begin{array}{l}\text { Institutions of the labour } \\
\text { market and welfare states } \\
\text { Unemployment rate } \\
\text { Gender } \\
\text { Age } \\
\text { Socio-economic class } \\
\text { Education } \\
\text { Part-time work } \\
\text { Limited work contract } \\
\text { Unemployment benefits* }\end{array}$ & $\begin{array}{l}\text { Autonomy } \\
\text { Job security } \\
\text { Job security } \\
\text { Job autonomy } \\
\text { Job security* }\end{array}$ & & \\
\hline Federici, 2013 & & Autonomy & Job satisfaction & \\
\hline Finn, 2001 & & Autonomy & Job satisfaction & \\
\hline $\begin{array}{l}\text { Jercovic-Cosic } \\
\text { et al., } 2012\end{array}$ & & $\begin{array}{l}\text { Skill variety } \\
\text { Autonomy }\end{array}$ & Job satisfaction & \\
\hline $\begin{array}{c}\text { Grip \& Wolbers, } \\
2006\end{array}$ & $\begin{array}{l}\text { Structure of education } \\
\text { and training system }\end{array}$ & $\begin{array}{l}\text { Labour market position } \\
\text { of the worker }\end{array}$ & & \\
\hline Hill et al., 2001 & & Perceived job flexibility & $\begin{array}{l}\text { Work-life } \\
\text { balance }\end{array}$ & \\
\hline Holman, 2013 & Institutional regimes & Job quality & & \\
\hline $\begin{array}{l}\text { Hosie et al., } \\
2013\end{array}$ & & $\begin{array}{l}\text { Autonomy } \\
\text { Training opportunities }\end{array}$ & Job satisfaction & \\
\hline $\begin{array}{l}\text { Kalleberg et al., } \\
2000\end{array}$ & $\begin{array}{l}\text { Nonstandard } \\
\text { employment }\end{array}$ & $\begin{array}{l}\text { Exposure to bad job } \\
\text { characteristics }\end{array}$ & & \\
\hline
\end{tabular}


Table 2

\begin{tabular}{|c|c|c|c|c|}
\hline 1 & 2 & 3 & 4 & 5 \\
\hline $\begin{array}{c}\text { Kelliher \& } \\
\text { Anderson, } 2008\end{array}$ & Flexible working & Job quality & & \\
\hline Kolev, 2005 & $\begin{array}{l}\text { Education } \\
\text { Age } \\
\text { Socio-economic status } \\
\text { People with disabilities }\end{array}$ & Job quality & & \\
\hline $\begin{array}{c}\text { Kuhnert et al., } \\
1989 \\
\end{array}$ & & Job security & Health & \\
\hline $\begin{array}{l}\text { Layte et al., } \\
2008\end{array}$ & $\begin{array}{l}\text { Fixed-term and casual } \\
\text { employment }\end{array}$ & $\begin{array}{l}\text { Working conditions } \\
\text { Hourly wage } \\
\text { Training } \\
\text { Autonomy }\end{array}$ & & \\
\hline Long, 1993 & Introduction of new IT & Job quality & & \\
\hline $\begin{array}{l}\text { Loughlin \& } \\
\text { Murray, } 2013\end{array}$ & & $\begin{array}{l}\text { Intrinsic work quality } \\
\text { Role stressors } \\
\text { Employment status } \\
\text { congruence }\end{array}$ & $\begin{array}{l}\text { Affective } \\
\text { organizational } \\
\text { commitment } \\
\text { Work-related } \\
\text { negative mood }\end{array}$ & $\begin{array}{l}\text { Organizational } \\
\text { citizenship } \\
\text { behaviour } \\
\text { Turnover } \\
\text { intentions } \\
\text { Psychological } \\
\text { and physical } \\
\text { health }\end{array}$ \\
\hline $\begin{array}{l}\text { McGovern et } \\
\text { al., } 2004 \\
\end{array}$ & $\begin{array}{l}\text { Nonstandard } \\
\text { employment }\end{array}$ & Bad job quality & & \\
\hline Mühlau, 2011 & Gender & Job quality & & \\
\hline $\begin{array}{c}\text { Okay- } \\
\text { Somerville \& } \\
\text { Scholarios, } \\
2013 \\
\end{array}$ & & $\begin{array}{l}\text { Opportunity for skill use } \\
\text { Job control } \\
\text { Job content }\end{array}$ & $\begin{array}{l}\text { Job satisfaction } \\
\text { Organizational } \\
\text { commitment } \\
\text { Well-being }\end{array}$ & \\
\hline $\begin{array}{c}\text { Piasna et al., } \\
2013 \\
\end{array}$ & $\begin{array}{l}\text { Employee participation } \\
\text { practices }\end{array}$ & Job quality & & \\
\hline $\begin{array}{l}\text { Smith et al., } \\
2008\end{array}$ & $\begin{array}{l}\text { Gender } \\
\text { Occupational status } \\
\text { Working time and sector }\end{array}$ & $\begin{array}{l}\text { Job content } \\
\text { Autonomy } \\
\text { Working conditions }\end{array}$ & & \\
\hline $\begin{array}{c}\text { Van Dun et al., } \\
2012\end{array}$ & & Job quality & $\begin{array}{l}\text { Job satisfaction } \\
\text { Employee turnover }\end{array}$ & $\begin{array}{l}\text { Employee } \\
\text { turnover }\end{array}$ \\
\hline Weaver, 1977 & & Autonomy & Job satisfaction & \\
\hline $\begin{array}{l}\text { Zeytinoglu et } \\
\text { al., } 2013\end{array}$ & & $\begin{array}{l}\text { Job security } \\
\text { Flexible employment* }\end{array}$ & $\begin{array}{l}\text { Job satisfaction } \\
\text { Job satisfaction* }\end{array}$ & \\
\hline Zipp, 1991 & Firm size & $\begin{array}{l}\text { Creativity } \\
\text { Interesting work } \\
\text { Autonomy } \\
\text { Overall job satisfaction }\end{array}$ & & \\
\hline
\end{tabular}

Sources: compiled by author

Second, there are a few studies that despite examining the relationships between the mentioned categories also developed the set of job quality dimensions (e.g., Brown et al., 2007; Holman, 2013; Kelliher \& Anderson, 2008). Finally, almost all of the reviewed studies that are related to the job quality concept were conducted in developed or developing countries. Some studies show that there is a 
correlation between the job quality and different macro-level factors such as economic environment (Cloutier-Villeneuve, 2012), social policies (Cloutier-Villeneuve, 2012) or unemployment rate (Brown et al., 2007; Esser \& Olsen, 2012). Therefore, there is a potential bias of the job quality researches in the underrepresentation of empirical studies in underdeveloped countries.

As it can be seen from the literature review, no agreed conceptual framework of job quality has been developed. In their empirical studies, scholars investigated only the separate correlations between the factors, elements and outcomes of job quality. And even in those researches, there is inconsistency in the definition of particular categories. For example, Zipp (1991) considers job satisfaction as an element of job quality, while most of the scholars (e.g., DeCarlo \& Agarwal, 1999; Jercovic-Cosic et al., 2012; Hosie et al., 2013) define it as an outcome. The only first attempt to generalize the empirical findings of job quality issue was made by Findlay et al. (2013). The authors consider job quality as a multidimensional phenomenon with multiple factors and forces operating at different levels and influencing it.

Based on the results of the initial evaluation of empirical studies, a general model of the factors and outcomes of job quality was built (Figure 1). In this model, job quality is a complex term that relates to the elements (dimensions) presented in Table 1. It integrates the common elements of job quality in the initially reviewed literature, such as autonomy, job content, job security, etc. The only element that was excluded from this construct is job satisfaction. Among the scholars, there is no agreed opinion whether job satisfaction is a dimension of job quality or its outcome. Some researchers identify job satisfaction as an element of job quality (e. g., Holman, 2012; Van Dun et al., 2012), however, most of them refers to it as an outcome. In our model, we decided to stick to the majority opinion excluding job satisfaction from job quality elements and placing it to the outcomes.

All the factors which influence job quality were combined in three broad groups: macro- level, organizational level and individual level factors. Macro-level factors are related to the level of socioeconomic development of the country, its policy, labour market stability and activity of labour market institutions. Organizational level factors refer to the objective characteristics of the company, such as sector and firm size, its HR policies, working conditions and material rewards it provides to the employee. Individual-level factors are objective, such as age or gender, and subjective, such as the perception of casual and permanent jobs, characteristics of the employee. The direct and indirect outcomes of job quality were integrated and generalized because there is inconsistency among the studies whether the particular outcome is direct or indirect. Some of the outcomes are directly related to the organization, such as organizational commitment, some are beneficial for the individual, such as psychological and physical health, while the most of them refer to both the organizational and individual consequences, such as job satisfaction or work-related mood.

Job quality and well-being. The European research project Walking suggested use employee's wellbeing as a measure of job quality outcome (European Commission, 2012). In this project, an aggregated measure based on the 38 indicators of job quality was developed, and each of the measures was proposed to be weighted according to the unique percentage of variance that it explains in three aspects of employee well-being (physical well-being, psychological well-being and job satisfaction). So, employee's well-being appears to be a complex measure that reflects different outcomes of job quality discussed above.

Other studies of Wright \& Bonett (1997) and Wright \& Cropanzano (2000) showed that well-being is predictive of employee's performance and found that employee's well-being was positively related to job performance ratings. So, promotion of employee's well-being is of considerable benefit to the employers and organization on the whole.

For those reasons in our meta-analysis of job quality, employee's well-being is used as an aggregated variable that integrates outcomes of job quality elements. 


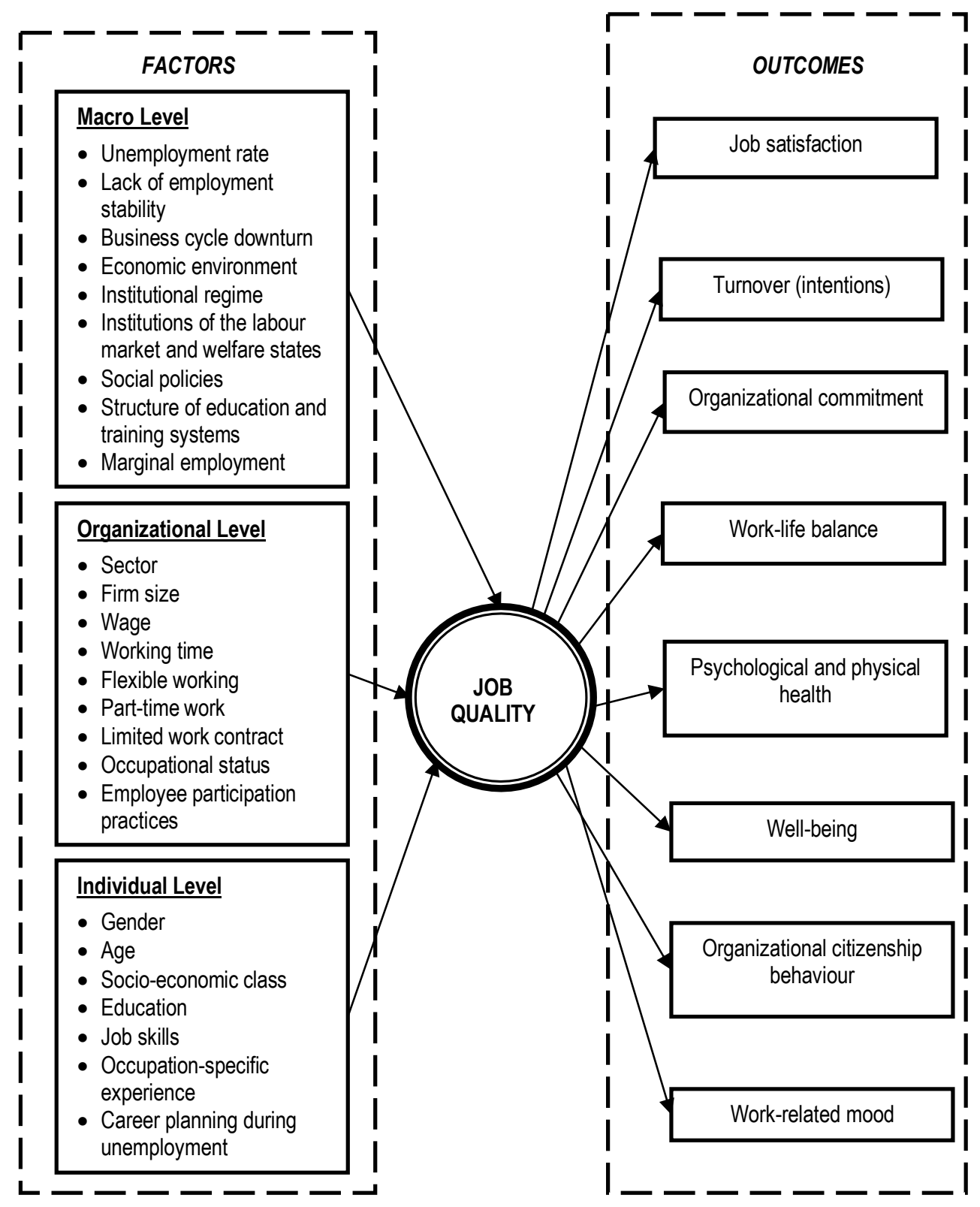

Figure 1 - General model of the factors and outcomes of job quality

Sources: developed by author

Subjective well-being. Among the researchers, two different views have been presented in the study field of well-being. Those two approaches are psychological well-being (PWB) and subjective well-being (SWB). SWB is a judgment about one's life in terms of satisfaction and reflection of positive and negative affect in one's immediate experience. This perspective emphasizes the hedonic aspect of well-being, 
which is the pursuit of happiness and a pleasant life (Chen et al., 2013). PWB refers to the perception of engagement with existential challenges of life. It focuses on eudaimonic well-being, which is the fulfilment of human potential and a meaningful life (Chen et al., 2013).

Scholars often debate whether there is a conceptual distinction between those two types of well-being. One point of view is that SWB and PWB have related-but-distinct status. Factor analysis of Keyes et al. (2002) showed that PWB and SWB are distinct dimensions, although both of them are closely related to the subjective nature of well-being. Another point of view proposes that those two types of well-being are two different research traditions rather than two fundamentally different concepts.

The study of Chen et al. (2013) examined the common variance shared by the two types of well-being and the unique variance specific to each. They found that when well-being is assessed at the higher level, SWB and PWB are strongly related at the general construct level. However, when their overlap with the general construct of well-being is partially out and well-being is evaluated with specific components, SWB and PWB seem to represent two distinguishable constructs (Chen et al., 2013). These results reveal that both concepts of well-being have merit on both general and specific levels of analysis.

As milestones in the well-being literature, books by Andrews \& Withey (1976) and Campbell et al. (1976) showed that although people live in an objectively defined world, they respond to the subjectively defined environment and do it differently. This subjective perception of reality can also be applied to the job. Employees evaluate the content of their jobs, work conditions, salary and other elements of job quality in comparison with their expectations and experiences. This evaluation leads to different outcomes, one of which is employee's well-being that is also perceived through the lens of subjective judgments. Since employees tend to perceive their job and its quality through their subjective lens, the subjective perspective on well-being is used for the analysis in this study.

SWB is a broad category that includes both people's emotional reactions to events as well as global evaluations of life (Diener \& Larsen, 1993; Diener et al., 1999). Those categories of SWB are defined as cognitive well-being and affective well-being. Cognitive well-being refers to domain-specific and global evaluations of life such as marital satisfaction or global life satisfaction; affective well-being refers to the frequency and intensity of positive and negative emotions arising in response to the events (Luhmann et al., 2012).

Most studies of the workplace environment characteristics on the employee's well-being mainly focus on affective well-being rather than a cognitive one as an indicator of job-related mental health (Jonge \& Schaufeli, 1998). That is why this study also addresses the employee's affective well-being.

Affective well-being. Affective well-being is a broad concept that reflects the frequent experience of positive effects and infrequent experience of negative effects (Diener \& Larsen, 1993). It can refer to two different levels of psychological perception. Firstly, affective well-being can be identified as context-free feelings about life in general, such as happiness, life satisfaction or depression (Warr, 1987; Warr, 1990). Secondly, it is affected that arises in relation to the specific domain (Warr, 1990). This effect can be either job-related or more narrowly facet-specific, for example, job satisfaction or satisfaction with pay respectively (Hosie et al., 2006). Warr $(1987,1990)$ was the first one who adopted affective well-being into work and employees. In general, an effective psychological state in relation to job indicates whether the employee feels good or not at work.

Structure of job-related affective well-being. In this article, the construct of affective well-being described by van Horn et al. (2004) is used as a basis for meta-analysis. This construct was developed as a result of the combination of two approaches to affective well-being proposed by Warr $(1987,1990)$ and Ryff (1989), Ryff \& Keyes (1995). According to the results of the initial literature search different elements of job quality was found to be related to such outcomes as job satisfaction and organizational commitment. Thus, in this meta-analysis, the construct of well-being refers to two sub-constructs - job satisfaction and affective organizational commitment. 
Job satisfaction. Within the organization sciences, job satisfaction is probably the most common, as well as the oldest operationalization of employee's well-being and workplace happiness (Wright, 2005). Job satisfaction is one of the employee attitudes that reflect the effective response to the job (Clegg et al., 1987). Scientists have defined and measured job satisfaction both as a global construct (Currivan, 1999) and as a concept with different dimensions (Price, 1997). Since this study is not focused on the examination of job quality - job satisfaction relationship, but rather on the relationship with the broader outcome of job quality (affective well-being), we use the global approach to job satisfaction over the dimensions one. We conceptualize job satisfaction as an overall degree to which an individual experiences positive and expressive state that is a result of one's own job or job experiences.

Scholars argue that the greater the number of satisfied employees in the organization is, the more effective it is (Robbins \& Judge, 2007). This can be explained by the fact that satisfied workers are more productive as compared to the workers who are not satisfied. So, job satisfaction as an element of employee's job-related affective well-being is closely related to organizational outcomes.

Affective organizational commitment. Organizational commitment can be understood as a force that links employees to the organization and makes them behave in a desire for organization way (Meyer et al., 2006). Meyer \& Allen (1991) identified three components of commitment as a psychological state, affective, continuance, and normative commitment. Each of the elements reflects a desire, need, and obligation to maintain employment in an organization respectively. As this article is focused on affective phenomena of employee's job-related well-being, organizational commitment is viewed as an affective form of commitment based on feelings of loyalty toward the organization.

As a part of the employee's job-related affective well-being, affective organizational commitment has been found to be positively associated with job performance (Mathieu \& Zajac, 1990; Meyer et al., 2002), and negatively associated with turnover intentions (Harris \& Cameron, 2005; Meyer et al., 2002). Thus, affective organizational commitment appears to be an important element of employee's well-being that has an influence on the organization's functioning and its outcomes.

Dimensions of job quality. Among the scholars, there is a variety of approaches to the study of job quality. Economists have a quite narrow point of view and focus on the remuneration level as a central dimension of job quality. For example, Goos \& Manning $(2003,2007)$ classify Britain labour market on good jobs and lousy jobs based on the approximation of well-paid jobs as good and poorly paid jobs as bad. On the contrary, organizational psychologists approach job quality by evaluating employee's subjective satisfaction. They focus much attention on intrinsic job characteristics that are supposed to provide positive job satisfaction.

The variety of perspectives on job quality issues leads to the conclusion that one limited definition of job quality, which is based on a certain approach, is not enough anymore. Job quality is not only about the level of pay or working conditions at the workplace. It is rather a complex category that integrates a broad set of dimensions. Moreover, recent debate at European Union has broadened the scope of job quality by adding the externally oriented elements such as job security, type of contract, etc. It was argued that job quality is not only what employee encounter at work but it also about the level of employment and employee-employer relationship regulations.

So each of the above-mentioned approaches to job quality has its advantages and disadvantages. For this reason, in this study, we did not focus on a certain perspective but rather tried to integrate them. In this meta-analysis, we chose one or a few most frequently used dimensions of job quality from different of the discussed approaches. From an economic approach, we picked the level of pay and integrated it with the psychological perspective in the form of pay satisfaction. From work and industrial sociological approach, we chose autonomy for further analysis. Finally, we added an externally oriented element of job quality that is job security dimension.

In this study, we examined the relationships between those three elements of job quality and its 
outcome - the employee's job-related affective well-being, in particular, job satisfaction and organizational commitment. The hypothesized model of job quality elements and outcomes that were meta-analysed is presented in Figure 2. By combining various dimensions, we aimed to analyse and compare the influence of traditional and new job quality elements on employee's affective well-being.

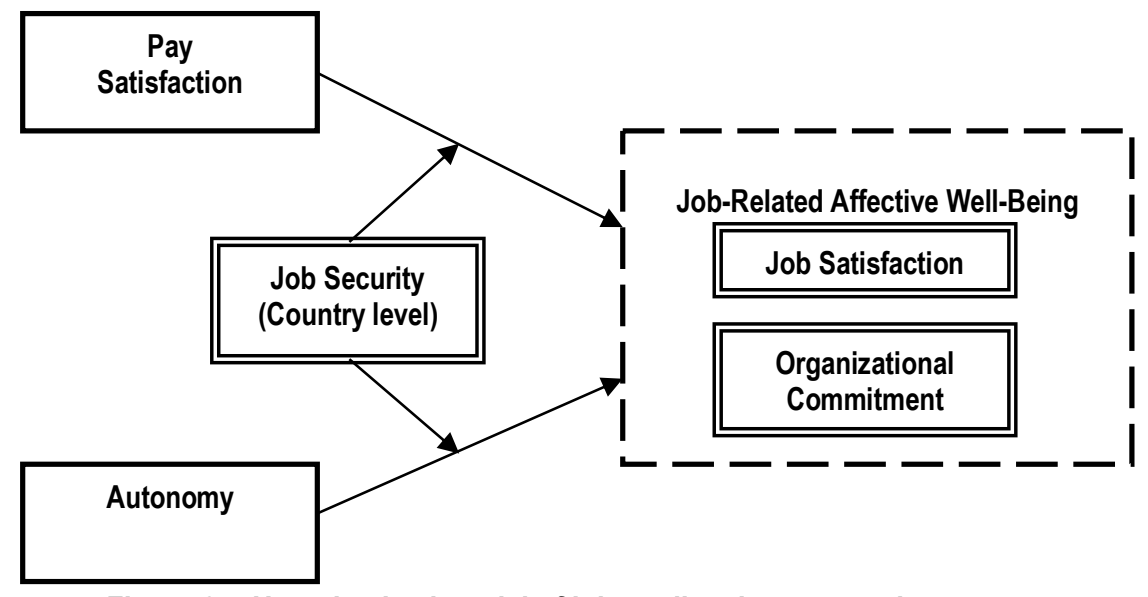

Figure 2 - Hypothesized model of job quality elements and outcomes

Sources: developed by author

Pay satisfaction and affective well-being. Among the rewards that the organization gives to its employees for their contribution, pay is argued to be a critical factor. However, employees tend to experience different feelings about their pay level that is mostly explained by the fact that pay allocation decisions usually perceived to be unfair. Consequently, pay level appears to be a controversial construct in terms of employee's perception and needs to be transformed into a more reliable measure of job quality. Therefore, we decided to choose pay satisfaction instead of pay level for our analysis.

Pay satisfaction is identified as employees' perceived satisfaction with their compensation package, particularly with their pay level, pay raises, and benefits, as well as the compensation system (Froese \& Xiao, 2012). However, pay satisfaction is not limited to the perceived satisfaction with the pay for previous work; it rather has a multidimensional nature (Carraher \& Buckley, 1996; Currall et al., 2005). Scholars proposed a variety of facets of pay satisfaction, among which there are job inputs, monetary and nonmonetary outcomes, the comparison process, and pay policies and administration - the latter referring to the systems and methods used to determine compensation. Those factors of pay satisfaction have been found to be related to different organizational outcomes, in particular, employee's affective well-being.

Pay satisfaction may affect job satisfaction and organizational commitment through different mechanisms. For instance, Williams et al. (2002) found benefit system satisfaction to be positively related to employee's overall job satisfaction. However, some other studies of the correlation between pay satisfaction and affective organizational commitment reported conflicting results. Malhotra et al. (2007) indicated that there is no significant relationship between those two variables. And the study of Eby et al. (1999) reported even negative correlation of pay satisfaction with affective commitment. Pay satisfaction may affect those components of affective well-being through different tools, but as it was reported in many empirical studies, we expect them to be positively correlated, such that:

Hypothesis 1 (H1): Level of pay satisfaction will be positively related to the employee's job-related affective well-being.

Autonomy and affective well-being. Job autonomy is a widely studied feature of work. Hackman \& 
Oldham (1975) identified autonomy as "the degree to which the job provides substantial freedom, independence, and discretion to the employee in scheduling the work and in determining the procedures to be used in carrying it out".

There have been a lot of research studies examining the relationship between autonomy and various job outcomes, such as satisfaction, commitment, and turnover (Marchese \& Ryan, 2001). On the one hand, De Cuyper \& De Witte (2006) found that autonomy is not predictive for the job satisfaction and organizational commitment of temporary employees. On the other hand, in his meta-analysis, Spector (1986) proved that autonomy is predictive of employee's job satisfaction and organizational commitment.

So, autonomy is not only the tool for organizations to enhance employee's job satisfaction and higher performance, but also an inborn human's need. The highly autonomous job allows the employee to determine the way of performing job tasks, their consequence, interaction with other employees and some other working conditions. When the performance of a certain job is not closely controlled, it is likely to give the employee a higher sense of autonomy and freedom in undertaking tasks. Therefore, a highly autonomous job will be expected to be positively correlated with employee's job satisfaction and organizational commitment, so that:

Hypothesis $2(\mathrm{H} 2)$ : Level of autonomy will be positively related to the employee's job-related affective well-being.

Moderating role of job security. Job security can be identified as an employee's evaluation of his or her current employment conditions and perception of his or her future in current job (Zeytinoglu et al., 2012). As a subjective phenomenon, job security refers to the employee's subjective assessment of how likely he or she is to lose the job in the near future. Objective conceptualization of job security reflects the employment conditions of the contract, working full-time hours and paid and unpaid overtime (Zeytinoglu et al., 2012).

The concept of job security has been widely studied and a lot of researchers proved that job security fear can lead to various negative organizational outcomes, such as decreased job satisfaction and stronger turnover intentions. However, scientists have recently started to consider job security as an element of job quality. In this relation, it appears to be interesting to investigate the moderating role of job security in the relationships between two relatively traditional elements of job quality - pay satisfaction and autonomy - and employee's job-related affective well-being.

Job security can moderate the relationship between pay satisfaction and affective well-being because of the human's needs not only to get deserved and sufficient financial reward but also to have a feeling of confidence in the future. If the employee was rewarded fairly and is satisfied with this reward, this pay satisfaction may not lead to high job satisfaction and organizational commitment. This link can be 'damaged' by the experienced feeling of insecurity in the employee's future in the organization. Job security can also enhance the positive correlation between autonomy and affective well-being. The sense of job security can give the employee more confidence to perform his or her task the way he or she considers being appropriate. Employees who feel confident in their future in the company tend to act more autonomously and, consequently, to experience higher subsequent job satisfaction as well as stronger desire to contribute to the achievement of organizational goals. Based on this, we argue that:

Hypothesis $3(\mathrm{H} 3)$ : The relationship between pay satisfaction and employee's job-related affective well-being will be moderated by job security such that pay satisfaction will be more positively associated with employee's job-related affective well-being when job security is high.

Hypothesis $4(\mathrm{H} 4)$ : The relationship between autonomy and job satisfaction will be moderated by job security, as a construct measured at the country level, such that the effect of autonomy will be stronger when job security is high, and weaker when job security is low.

The methodology of meta-analysis. We used meta-analysis to examine the hypothesized relationships between pay satisfaction, autonomy and employee's job-related affective well-being and the 
moderating role of job security. Meta-analysis is a way to qualitatively integrate the results of empirical studies. It can be understood as a form of survey research in which research reports, rather than people, are surveyed and summarized into the single set of numbers (Lipsey \& Wilson, 2001; Mullen, 1989). Metaanalysis is particularly useful when a lot of studies have already been conducted on a given topic. It has been frequently used to examine whether the relationship between variables remains relatively constant across various research settings or it changes under the influence of one or more moderators (Rogelberg, 2002). The main purpose of meta-analysis is to calibrate basic relationships among previously studied variables at the construct level (Hunter \& Schmidt, 2004).

The first stage of meta-analysis, as of any research method, is the collection of relevant data. A thorough literature search was conducted to collect the reports that examined the relationship between the elements and outcomes of job quality we were meta-analysing. The studies included in the analysis consisted of published articles available online. The relevant published articles were identified through an electronic search of the PsychINFO database using the following keywords, autonomy, job security, pay satisfaction, extrinsic satisfaction, pay, job satisfaction, organizational commitment. In order to eliminate inappropriate articles at this stage, the search was limited to the articles that contain mentioned keywords in the abstract, was written on English, and was published in peer-reviewed journals. Using those search criteria, we identified a population of 513 articles.

Inclusion criteria. The articles obtained from the conducted search were reviewed for further inclusion in the meta-analysis. The content of the articles was carefully checked. In the final list of studies for metaanalysis, we included the studies that (1) were empirical in nature, (2) provided the data necessary for calculating the effect size, (3) reported the correlations between at least two variables identified in the hypothesized model. Those three criteria were applied to the whole population of the studies we found. However, for the analysis of the moderating role of job security, we had one additional criterion that (4) the study was conducted in the country which is a member of the Organization for Economic Co-operation and Development (OECD). The last criterion was included because the OECD's Job Security Index was used for further studies' coding. We excluded the studies that reported correlations between the variables that are inverse to ones we were examining, for instance, lack of autonomy instead of autonomy. On the basis of those criteria, we retained 109 studies for the analysis. Since 17 of the studies contained two samples, two studies contained three samples and one study contained four samples, we worked with a total of 153 samples.

Coding \& procedures. At the next stage of meta-analysis, we performed a process of coding relevant studies. Coding is one of the most important steps of meta-analysis, therefore it is essential to do it appropriately and accurately (Hunter \& Schmidt, 2004).

Firstly, we assigned a certain number to every study that is called Study ID. As it was mentioned before, there are studies with a few samples and each with different correlations that were included in meta-analyses. We coded those Samples with study separately and in further analyses, they were treated as separate studies. The sample size $(\mathrm{N})$ was also included in addition to the Study ID.

Secondly, coding of the studies included the effect size in the form of correlations, $r$, and the reliability in the form of Cronbach's alpha, a.

For the analysis of job security as a moderator of the hypothesized relationships, it was important to code different levels of job security separately. In order to do this, we firstly coded the country of each study. Afterwards, based on the OECD's Job Security Index, we coded all studies according to the high or low level of job security in the country where the study was conducted. According to the OEDC (2012), in 2012 on average in OECD countries, workers face a 5.3\% chance of losing their job. The countries with the higher chance of losing job were coded as low job security countries, for example, Canada, Spain, USA. The countries that were reported to have a lower than average chance of losing job were coded as countries with high job security, for instance, Belgium, Germany, the Netherlands. 
In order to calculate the relationship between job security at the individual level and job satisfaction, 14 studies, were utilized, and for the relationship between job security and organization commitment, 13 studies were used. Taking the multiple samples within some studies into account, a total number of 21 and 20 samples respectively were used.

For the calculation of the relationship between pay satisfaction and job satisfaction, 22 studies were utilized, and for the relationship between pay satisfaction and organizational commitment, 13 studies were used. Taking the multiple samples within some studies into account, a total number of 27 and 15 samples respectively were used.

Similarly, for the calculation of the relationship between autonomy and job satisfaction, 54 studies were utilized, and for the relationship between autonomy and organization commitment, 35 studies were used. However, when taking the multiple samples within some studies into account, a total number of 65 and 40 samples respectively were used.

Results. In Table 3, the result of the meta-analysis of the relationship between pay satisfaction and job-related affective well-being are presented. It includes the overall relationship between pay satisfaction and job satisfaction and organizational commitment as well as the results of moderator analysis.

Table 3 - Meta-analysis results of the moderating role of job security at the country level on the relationship between pay satisfaction and job-related affective well-being

\begin{tabular}{|c|c|c|c|c|c|c|c|c|c|}
\hline & \multirow{2}{*}{$\mathrm{k}$} & $\mathrm{N}$ & $\mathrm{r}$ & \multirow{2}{*}{$\rho$} & \multirow{2}{*}{$\mathrm{SD} \rho$} & \multicolumn{2}{|c|}{$80 \%$ C.V. } & \multicolumn{2}{|c|}{$95 \%$ C.I. } \\
\cline { 8 - 11 } & & & & & & Lower & Upper & Lower & Upper \\
\hline Job Satisfaction & $\mathbf{2 2}$ & $\mathbf{5 8 , 5 3 7}$ & $\mathbf{0 , 3 2}$ & $\mathbf{0 , 4 6}$ & $\mathbf{0 , 1 8}$ & $\mathbf{0 , 2 3}$ & $\mathbf{0 , 6 9}$ & $\mathbf{0 , 4 2}$ & $\mathbf{0 , 5 0}$ \\
\hline High Job Security & 20 & 57,081 & 0,32 & 0,47 & 0,18 & 0,23 & 0,70 & 0,43 & 0,51 \\
\hline Low Job Security & 2 & 1,456 & 0,27 & 0,32 & 0,09 & 0,20 & 0,44 & 0,23 & 0,42 \\
\hline $\begin{array}{c}\text { Organizational } \\
\text { Commitment }\end{array}$ & $\mathbf{1 3}$ & $\mathbf{3 5 , 1 1 7}$ & $\mathbf{0 , 2 9}$ & $\mathbf{0 , 4 1}$ & $\mathbf{0 , 1 0}$ & $\mathbf{0 , 2 8}$ & $\mathbf{0 , 5 3}$ & $\mathbf{0 , 3 7}$ & $\mathbf{0 , 4 5}$ \\
\hline High Job Security & 11 & 34,243 & 0,29 & 0,41 & 0,10 & 0,28 & 0,53 & 0,37 & 0,44 \\
\hline Low Job Security & 2 & 0,874 & 0,37 & 0,43 & 0,07 & 0,34 & 0,52 & 0,32 & 0,53 \\
\hline
\end{tabular}

Note: $\mathrm{k}=$ number of studies; $\mathrm{N}=$ respondents in studies; $r=$ uncorrected population correlation; $\rho=$ corrected population correlation; $\mathrm{SD} \rho=$ standard deviation of corrected population correlation; $\mathrm{CV}=$ credibility interval; $\mathrm{Cl}=$ confidence interval.

Sources: developed by author

Hypothesis 1 (level of pay satisfaction will be positively related to the employee's job-related affective well-being) is supported by the results of the meta-analysis. As was hypothesized, the overall analysis of pay satisfaction and job-related affective well-being revealed a positive relationship between those two constructs. Particularly, the overall population value of the relationship between pay satisfaction and job satisfaction is moderately strong $(\rho=0.46)$, and the relationship between pay satisfaction and organizational commitment is also moderately strong $(\rho=0.41)$. Neither the confidence interval nor the credibility interval for those correlations included zero. Sampling error variance and population correlations variance ratio for the pay satisfaction - job satisfaction and pay satisfaction - organizational commitment relationships are $1.16 \%$ and $3.53 \%$ respectively. This is lower than the rule of thumb of $75 \%$, which indicates that a moderating variable may have been present in the data.

Conclusion. The theoretical relevance of the study is to fill the research gap in the literature concerning the topic of job quality. The interest to the concept of job quality among the scholars and international institutions renewed over the last decade. The number of researches concerning this topic is increasing, however, still limited and almost all of them are empirical in nature. The generalized model of job quality issue and the meta-analysis of the key empirical findings will, therefore, be a new aspect in the scientific literature. The first contribution of the research with regard to the literature is a comprehensive 
summary of the available information on job quality elements as well as factors that influence it and its outcomes. In the developed general model of the job quality construct, the results of the various quantitative and qualitative studies of job quality are integrated into one framework. This framework can be used as a starting point for more in-depth research of the job quality construct.

All of the reviewed articles report the results of the empirical studies without an attempt to combine them and, consequently, identify patterns among those results, sources of disagreement among them, or other interesting relationships that may come to light in the context of multiple studies. In relation to this, another theoretical contribution of this study is the first meta-analytical summary of the relationships between the three most widely studied elements of job quality - job security, pay satisfaction, and autonomy - and job quality outcome - the employee's job-related affective well-being. This study provides the population correlation estimates between those variables that were calculated based on the results of 109 empirical studies. Finally, the findings of this study explain the effect of the relatively new dimension of job quality - job security, as a construct measured on the individual and country level, - on the job quality construct. Findings of this article can be helpful in understanding the growing importance of job security in the context of a rapidly changing the business environment as well as the necessity to include it in the construct of job quality.

Although the relevance of this study is mainly theoretical, there is some practical relevance for international institutions, policy-makers, and companies' managers. The developed general model of job quality, as well as the meta-analysis of some of its relationships, can provide insight into understanding better the policy-relevant issue of job quality for policy-makers. Moreover, this study can also be useful for the company's managers. Its findings provide organizations with some directions for the design of the workplaces that are expected to be attractive for employees as well as for the development of various motivational mechanisms in response to the rapidly changing human's needs and business environment. Specifically, under the conditions of low country level job security, which results in the increased external uncertainty, perceived by employees, managers can use pay satisfaction and autonomy as instruments to improve the employees' job-related affective well-being. In particular, pay satisfaction can be used for the enhancement of employees' job satisfaction, and autonomy appears to be a powerful tool for the increase in both employees' job satisfaction and commitment to the company.

\section{References}

Andrews, F. M., \& Withey, S. B. (1976). Social indicators of well-being: Americans' perceptions of life quality. New York: Plenum. Brand, J. E. (2006). The effects of job displacement on job quality: Findings from the Wisconsin Longitudinal Study. Research in Social Stratification and Mobility, Vol. 24, pp. 275-298.

Brown, A., Charlwood, A., Forde, C., \& Spencer, D. (2007). Job quality and the economics of New Labour: a critical appraisal using subjective survey data. Cambridge Journal of Economics, Vol. 31, pp. 941-971.

Caliendo, M., Künn, S., \& Uhlendorff, A. (2012). Marginal employment, unemployment duration and job match quality. DIW Berlin Discussion Paper, No. 6499, pp. 1-29.

Campbell, A., Converse, P. E., \& Rodgers, W. L. (1976). The quality of American life: Perceptions, evaluations, and satisfactions. New York: Russell Sage Foundation.

Carraher, S. M., \& Buckley, M. R. (1996). Cognitive complexity and the perceived dimensionality of pay satisfaction. Journal of Applied Psychology, Vol. 81, No. 1, pp. 102-109.

CEC (2001b). Employment in Europe 2001. Brussels, Commission of the European Communities.

CEC (2003). Improving quality in work: A review of recent progress. COM Commission of the European Communities 2003/728, 26 November 2003.

Chalmers, J., Campbell, I., \& Charlesworth, S. (2005). Part-time work and caring responsibilities in Australia: Towards an assessment of job quality. Labour \& Industry, Vol. 15, No. 3, pp. 41-66.

Chen, F. F., Jing, Y., Hayes, A., \& Lee, J. M. (2013). Two concepts or two approaches? A bifactor analysis of psychological and subjective well-being. Journal of Happiness Studies, Vol. 14, No. 3, pp. 1033 - 1068.

Clegg, C., Wall, T., \& Kemp, N. (1987). Women on the assembly line: A comparison of the main interactive and explanations of job satisfaction, absence and mental health. Journal of Occupational Psychology, Vol. 60, No. 4, pp. 273-287. 
Cloutier-Villeneuve, L. (2012). Job quality in Quebec and the United Kingdom: Trends by sex and family status, 1998-2008. International Labour Review, Vol. 151, No. 1-2, pp. 61-84.

Cooke, G. B., Donaghey, J., \& Zeytinoglu, I. U. (2013). The nuanced nature of work quality: Evidence from rural Newfoundland and Ireland. Human Relations, Vol. 66, No. 4, pp. 503-528.

Currall, S. C., Towler, A. J., Judge, T. A., \& Kohn, L. (2005). Pay satisfaction and organizational outcomes. Personne/ Psychology, Vol. 58, No. 3, pp. 613-640.

Currivan, D. B. (1999). The causal order of job satisfaction and organizational commitment in models of employee turnover. Human Resource Management Review, Vol. 9, No. 4, pp. 495-524.

DeCarlo, T. E., \& Agarwal, S. (1999). Influence of managerial behaviors and job autonomy on job satisfaction of industrial salespersons: A cross-cultural study. Industrial Marketing Management, Vol. 28, pp. 51-62.

De Cuyper, N, \& De Witte, H. (2006). Autonomy and workload among temporary workers: Their effects on job satisfaction, organizational commitment, life satisfaction, and self-rated performance. International Journal of Stress Management, 13(4)б 441459 .

Diener, E. \& Larsen, R.J. (1993). The experience of emotional well-being. In M. Lewis and J.M. Havilland (Eds), Handbook of emotions. New York: Guildford Press.

Diener, E., Suh, E. M., Lucas, R. E., \& Smith, H. L. (1999). Subjective well-being: Three decades of progress. Psychological Bulletin, Vol. 125, pp. 276-302.

Drobnic, S., \& Rodriguez, A. M. G. (2011). Tensions between work and home: Job quality and working conditions in the institutional contexts of Germany and Spain. Social Politics, Vol. 18, No. 2, pp. 232-268.

Dupre, K. E., \& Day, A. L. (2007). The effect of supportive management and job quality on the turnover intensions and health of military personnel. Human Resource Management, Vo. 46, No. 2, pp. 185-201.

Eby, L. T., Freeman, D. M., Rush, M. C. and Lance, C. E. (1999). Motivational bases of affective organizational commitment: A partial test of an integrative theoretical model. Journal of Occupational and Organizational Psychology, Vol. 72 No. 4, pp. 463-483.

Esser, I., \& Olsen, K. M. (2012). Perceived job quality: autonomy and job security within a multi-level framework. European Sociological Review, Vol. 28, No. 4, pp. 443-454.

European Commission (2001). Employment and Social Policies: A Framework for Investing in Quality. Brussels. Commission of the European Communities.

European Commission (2012). New skills and jobs in Europe: Pathways towards full employment. Luxembourg: Publications Office of the European Union.

Federici, R. A. (2013). Principals' self-efficacy: relations with job autonomy, job satisfaction, and contextual constraints. European Journal of Psychology of Education, Vol. 28, pp. 73-86.

Findlay, P., Kalleberg, A. L., \& Warhurst, C. (2013). The challenge of job quality. Human Relations, Vol. 66, No. 4, pp. 441-451.

Finn, C. P. (2001). Autonomy: an important component for nurses' job satisfaction. International Journal of Nursing Studies, Vol. 38, pp. 349-357.

Froese, F. J., \& Xiao, S. (2012). Work values, job satisfaction and organizational commitment in China. The International Journal of Human Resource Management, Vol. 23, No. 10, pp. 2144-2162.

Goos, M., \& Manning, A. (2003). McJobs and MacJobs: The growing polarization of jobs in the UK. In: Dickens, R., Gregg, P., \& Wadsworth, J. The labour market under new labour. Basingstoke, UK: Palgrave Macmillan, pp. 70-85.

Goos, M., \& Manning, A. (2007). Lousy and lovely jobs: The rising polarization of work in Britain. Review of Economics and Statistics, Vol. 89, pp. 118-133.

Green, F. (2006). Demanding Work: The Paradox of Job Quality in the Affluent Economy. Oxford: Princeton University Press.

Grip A., \& Wolbers, M. H. J. (2006). Cross-national differences in job quality among low-skilled young workers in Europe. International Journal of Manpower, Vol. 27 No. 5, pp. 420-433.

Hackman, J. R., \& Oldham, G. R. (1975). Development of the job diagnostic survey. Journal of Applied Psychology, Vol. 60, No. 2, pp. 159-170.

Handel, M. J. (2005). Trends in perceived job quality, 1989 to 1998. Work and Occupations, Vol. 32, No. 1, pp. 66-94

Harris, G. E., \& Cameron, J. E. (2005). Multiple dimensions of organizational identification and commitment as predictors of turnover intentions and psychological well-being. Canadian Journal of Behavioural Science, Vol. 37, No. 3, pp. 159-169.

Hill, E. J., Hawkins, A. J., Ferris, M., \& Weitzman, M. (2001). Finding an extra day a week: The positive influence of perceived job flexibility on work and family life balance. Family Relations, Vol. 50, No. 1, pp. 49-58.

Holman, D. (2012). Job types and job quality in Europe. Human Relations, Vol. 66, №. 4, pp. 475-502.

Hosie, P.J., Jayashree, P., Tchantchane, A., \& Lee, B. C. (2013). The effect of autonomy, training opportunities, age and salaries on job satisfaction in the South East Asian retail petroleum industry. The International Journal of Human Resource Management, Vol. 24, No. 21, pp. 3980-4007.

Hosie, P.J., Sevastos, P.P., \& Cooper, C.L. (2006). Happy-performing managers: The impact of affective wellbeing and intrinsic job satisfaction in the workplace. Cheltenham, UK, Northhampton, MA, USA: Edgar Elgar. Sage.

Hunter, J. E., \& Schmidt, F. L. (2004). Methods of meta-analysis. Correcting error and bias in research findings, $2^{\text {nd }}$ edn. London: 
ILO (International Labor Organization) (1999). Job quality and small enterprise development. Series on Job Quality in Micro and Small Enterprise Development, Working paper No. 4, pp. 1-26.

ILO (2014). Mainstreaming decent work. Retrieved on 1 February 2014 via http://www.ilo.org/integration /themes/dw_mainstreaming/lang--en/index.htm

Jerkovic-Cosic, K., Van Offenbeek, M., \& Van der Schans, C. (2012). Job satisfaction and job content in Dutch dental hygienists. International Journal of Dental Hygiene, Vol. 10, pp. 155-162.

Jonge, J. D., \& Schaufeli, W. B. (1998). Job characteristics and employee well-being: A test of Warr's Vitamin Model in health care workers using structural equation modeling. Journal of Organizational Behavior, Vol. 19, pp. 387-407.

Kalleberg, A. L., Reskin, B. F., \& Hudson, K. (2000). Bad jobs in America: Standard and nonstandard employment relations and job quality in the United States. American Sociological Review, Vol. 65, No. 2, pp. 256-278.

Kalleberg, A. L., \& Vaisey, S. (2005). Pathways to a good job: Perceived work quality among the machinists in North America. British Journal of Industrial Relations, Vol. 43, No. 3, pp. 431-454.

Kelliher, C., \& Anderson, D. (2008). For better or for worse? An analysis of how flexible working practices influence employees' perceptions of job quality. The International Journal of Human Resource Management, Vol. 19, No. 3, pp. 419-431.

Keyes, C. L. M., Shmotkin, D., \& Ryff, C. D. (2002). Optimizing well-being: The empirical encounter of two traditions. Journal of Personality and Social Psychology, Vol. 82, No. 6, pp. 1007-1022.

Knox, A., Warhurst, C., \& Pocock, B. (2011). Job Quality Matters. Journal of Industrial Relations, Vol. 53, No. 1, pp. 5-11.

Kolev, A. (2005). Unemployment, job quality and poverty: A case study of Bulgaria. International Labour Review, 144 (1), $85-$ 114.

Kuhnert, K. W., Sims, R. R., \& Lahey, M. A. (1989). The relationship between job security and employee health. Group \& Organization Management, Vol. 14, No. 4, pp. 399-410.

Layte, R., O'Connell, P. J., \& Russell, H. (2008). Temporary jobs in Ireland: Does class influence job quality? The Economic and Social Review, Vol. 39, No. 2, pp. 81-104.

Lipsey, M. W., \& Wilson, D. B. (2001). Practical meta-analysis. Applied social research methods series. Vol. 49.

Long, R. J. (1993). The impact of new office information technology on job quality of female and male employees. Human

Relations, Vol. 46, No. 8, pp. 939-961.

Loughlin, C., \& Murray, R. (2013). Employment status congruence and job quality. Human Relations, Vol. 66, No. 4, $529-553$.

Luhmann, M., Hawkley, L. C., Eid, M., \& Cacioppo, J. T. (2012). Time frames and the distinction between affective and cognitive well-being. Journal of Research in Personality, Vol. 46, pp. 431-441.

Malhotra, N., Budhwar, P., \& Prowse, P. (2007). Linking rewards to commitment: An empirical investigation of four UK call centres. International Journal of Human Resource Management, Vol. 18 No. 12, pp. 2095-2128.

Marchese, M. C., \& Ryan, J. (2001). Capitalizing on the benefits of utilizing part-time employees through job autonomy. Journal of Business and Psychology, Vol. 15, No. 4, pp. 549-560.

Mathieu, J. E., \& Zajac, D. M. (1990). A review and meta-analysis of the antecedents, correlates, and consequences of organizational commitment. Psychological Bulletin, Vol. 108, No. 2, pp. 171-194.

McGovern, P., Smeaton, D., \& Hill, S. (2004). Bad jobs in Britain: nonstandard employment and job quality. Work and Occupations, Vol. 31, No. 2, pp. 225-249.

Meyer, J. P., \& Allen, N. J. (1991). A three-component conceptualization of organizational commitment. Human Resource Management Review, Vol. 1, No. 1, pp. 61-89.

Meyer, J. P., Becker, T. E., \& Van Dick, R. (2006). Social identities and commitments at work: Toward an integrative model. Journal of Organizational Behavior, Vol. 27, No. 5, pp. 665-683.

Meyer, J. P., Stanley, D. J., Herscovitch, L., \& Topolnytsky, L. (2002). Affective, continuance, and normative commitment to the organization: A meta-analysis of antecedents, correlates, and consequences. Journal of Vocational Behavior, Vol. 61, pp. $20-52$. Mühlau, P. (2011). Gender inequality and job quality in Europe. Management Revue, Vol. 22, No. 2, pp. 114-131.

Mullen, B. (1989). Advanced BASIC Meta-analysis. Hillsdale, New Jersey: Lawrence Erlbaum.

Okay-Somerville, B., \& Scholarios, D. (2013). Shades of grey: Understanding job quality in emerging graduate occupations. Human Relations, Vol. 66, No. 4, pp. 555-585.

Piasna, A., Smith, M., Rose, J., Rubery, J., Burchell, B., \& Rafferty, A. (2013). Participatory HRM practices and job quality of vulnerable workers. The International Journal of Human Resource Management, Vol. 24, No. 22, pp. 4094-4115.

Price, J.L. (1997). Handbook of Organizational Measurement, MCB University Press, Bradford.

Robbins, S., \& Judge, T. (2007). Organizational Behavior. Upper Saddle River, NJ: Pearson Prentice Hall.

Rogelberg, S. G. (2002). Handbook of research methods in industrial and organizational psychology. Oxford: Blackwell

Publishers Ltd.

Ryff, C. D. (1989). Happiness is everything, or is it? Exploration of the meaning of psychological well-being. Journal of Personality and Social Psychology, Vol. 57, No. 6, pp. 1069-1081.

Ryff, C. D. \& Keyes, C. L. M. (1995). The structure of psychological well-being revisited. Journal of Personality and Social Psychology, Vol. 69, No. 4, pp. 719-727.

Smith, M., Burchell, B., Fagan, C., \& O’Brien, C. (2008). Job quality in Europe. Industrial Relations Journal, Vol. 39, No. 6, pp. 586-603. 
Spector, P. E. (1986). Perceived control by employees: A meta-analysis of studies concerning autonomy and participation at work. Human Relations, Vol. 39, No. 11, pp. 1005-1016.

Van Dun, Z., Bloemer, J., \& Henseler, J. (2012). Job quality in the customer contact centre: Conceptual foundation and scale development. The Service Industries Journal, Vol. 32, No. 2, pp. 171-196.

Warr, P. B. (1987). Work, unemployment and mental health. Oxford, United Kingdom: Clarendon Press.

Warr, P. B. (1990). The measurement of well-being and other aspects of mental health. Journal of Occupational Psychology,

Vol. 63, No. 3, pp. 193-210.

Weaver, C. N. (1977). Relationship among pay, race, sex, occupational prestige, supervision, work autonomy, and job satisfaction in a national sample. Personnel Psychology, Vol. 30, pp. 437-445.

Williams, M. L., Malos, S. B., \& Palmer, D. K. (2002). Benefit system and benefit level satisfaction: An expanded model of antecedents and consequences. Journal of Management, Vol. 28, No. 2, pp. 195-215.

Wright, T. A., \& Bonett, D. G. (1997). The role of pleasantness and activation-based well-being in performance prediction. Journal of Occupational Health Psychology, Vol. 2, pp. 212-219.

Wright, T. A., \& Cropanzano, R. (2000). Psychological well-being and job satisfaction as predictors of job performance. Journal of Occupational Health Psychology, Vol. 5, No. 1, pp. 84-94.

Zeytinoglu, I. U., Yilmaz, G., Keser, A., Inelmen, K., Uygur, D., \& Özsoy, A. (2013). Job satisfaction, flexible employment and job security among Turkish service sector workers. Economic and Industrial Democracy, Vol. 34, No. 1, pp. 123-144.

Zeytinoglu, I. U., Keser, A., Yılmac, G., Inelmen, C., Ozsoy, A., \& Uygur, D. (2012). Security in a sea of insecurity: job security and intention to stay among service sector employees in Turkey. The International Journal of Human Resource Management, Vol. 23, No. 13, pp. 2809-2823.

Zipp, J. F. (1991). The quality of jobs in small businesses. Economic Development Quarterly, Vol. 5, No. 9, pp. 9-22.

А. Швець, компанія Signify (Нідерланди).

Інноваційні підходи до аналізу якості праці: фактори, елементи та результати

Метою дослідження $\epsilon$ систематизація загальних та конкретних уявлень про якість праці. Дослідження містить узагальнення та структурування світової наукової спадщини щодо концепції якості праці та добробуту, задоволеності працею та співвідношення між цими категоріями. Підкреслено, що протягом багатьох років концепція якості праці була досліджена вченими різних галузей, широко обговорювалася та досліджувалася розробниками політики праці. Якість праці стала широко обговорюваною проблемою через ії важливість у формуванні працівника, компанії та, як наслідок, національного добробуту. Авторами запропоновано інноваційні підходи до аналізу якості праці, які знайшли своє відображення в п'яти частинах статті, кожна з яких стосується дослідження певних аспектів якості праці. У першій частині статті проаналізовано концептуальні погляди щодо якості праці та ї̈ характеристик. На підставі результатів первинної оцінки емпіричних досліджень була побудована загальна модель факторів та результатів якості праці. Друга частина статті присвячена теоретичному вивченню основних категорій, таких як якість праці та добробут, суб'єктивний добробут та афективне самопочуття, задоволеність працею, афективна організаційна відданість. Обгрунтовано структуру афективного добробуту, пов'язаного з працею. Конструкція афективного добробуту використовується як основа для мета-аналізу. Згідно з результатами дослідження літературних джерел, різні характеристики якості праці пов'язані з такими результатами, як задоволеність працею та організаційні зобов'язання. Третя частина статті містить дослідження рівня якості та обсягу праці. Три аспекти якості праці задоволення, автономія та безпека праці - були систематизовані стосовно афективного добробуту працівника. Розроблено гіпотетичну модель елементів якості праці та проаналізовано їі результати. Четверта частина статті містить мета-аналіз ключових аспектів загальної концепції та загальної моделі конструкції якості праці, яка складається з факторів якості праці, елементів і результатів. Дослідження дозволяє отримати аналітичний результат, який базується на методі психометричного мета-аналізу, та характеризує зв'язок між безпекою праці, задоволеністю працею, автономією та афективним добробутом працівника. П'ята частина статті містить результати мета-аналізу. У статті представлено результати взаємозв'язку безпеки праці на індивідуальному рівні та афективного добробуту, пов'язаного із працею. Виокремлено результати взаємозв'язку задоволеності оплатою праці та афективним добробутом. Отримано кількісні результати взаємозв'язку між автономією та афективним добробутом, пов'язаним із працею. Отримані результати також містять аналіз впливу безпеки праці на ці взаємозв'язки.

Ключові слова: інноваційний підхід, якість праці, безпека робочих місць, автономія, мета-аналіз, задоволеність працею.

Manuscript received: 31.10 .2018

(c) The author(s) 2018. This article is published with open access at Sumy State University. 